\title{
Presence of a urinary bladder in Egernia depressa (Squamata: Scincidae) in Western Australia
}

\author{
Christopher J. Bell ${ }^{1}$, Marci G. Hollenshead ${ }^{2}$, Jim I. Mead ${ }^{3}$ and Sandra L. Swift ${ }^{3}$ \\ ${ }^{1}$ Department of Geological Sciences, Jackson School of Geosciences, The University of Texas at Austin, Austin, Texas \\ 78712 U.S.A. E-mail: cjbell@mail.utexas.edu \\ ${ }^{2}$ Department of Biological Sciences, Northern Arizona University, Flagstaff, Arizona 86011 U.S.A. \\ E-mail: mgh7@nau.edu
}

${ }^{3}$ Don Sundquist Center of Excellence in Paleontology and Department of Geosciences, Box 70357, East Tennessee State University, Johnson City, Tennessee 37614 U.S.A. E-mails: MEAD@etsu.edu \& sandra.swiftone@yahoo.com

Correspondence to: Christopher J. Bell; cjbell@mail.utexas.edu

\section{INTRODUCTION}

Although a urinary bladder is present within Testudines, Sphenodon and at least some amphisbaenians (Cope 1900; Fox 1977; Minnich 1982), it is absent in crocodilians and snakes (Bentley 1979) as well as many lizards (Bentley 1979; Minnich 1982; Beuchat 1986). A summary table of lizard species known to possess a urinary bladder was provided by Beuchat (1986), and contrary to earlier generalizations of its widespread presence among lizards (e.g. Fox 1977) it is variably present within many clades. Its presence and size vary intraspecifically and with ontogenetic stage in at least some taxa, with known variation best explored and understood in the iguanians (Mulaik 1946; Beuchat et al. 1985; Beuchat 1986). It is clearly present in neonates of several phrynosomatid lizards that lack a urinary bladder as adults (Beuchat et al. 1985), or retain only a vestigial structure known as a 'bladder stalk' (Mulaik 1946).

Among skinks (Scincidae), a urinary bladder is known to be present only within Chalcides mionecton, Plestiodon fasciatus (reported as Eumeces), Plestiodon obsoletus (originally reported as Eumeces guttulatus), Feylinia currori, Ctenotus leonhardii (reported as Lygosoma taeniolatum), Scincus scincus (reported as Scincus officinalis), Tiliqua rugosa (reported as Trachydosaurus rugosus) and Tiliqua scincoides (Brooks 1906; Reynolds 1939; Gabe and Saint Girons 1965; Goddard 1969; Bentley 1976; Beuchat 1986). To that list may now be added the Australian skink Egernia depressa. Interestingly, Scincidae was one of only three families in which a urinary bladder was consistently reported by Beuchat (1986). However, in light of the physiological significance of functional bladders, and given the limited availability of data within the speciose Scincidae clade, variation within other squamate clades, and ontogenetic and intraspecific variation in the presence or condition of a bladder, it is important to document all known occurrences, as well as known absences, of the urinary bladder.

\section{MATERIALS AND METHODS}

On 4 June 2005, we collected 10 specimens of the northern, saxicolous form of Egernia depressa in a boulder field southwest of Nanutarra along the Northwest Coastal Highway in the Pilbara District of Western Australia. Specimens were collected as part of an effort to build a skeletal collection for the Western Australian Museum (WAM), and, after liver tissues were collected, were field-dressed and dried as a preliminary step in skeletonization. During initial preparation (skinning and eviscerating) we noted that each individual released a substantial volume of fluid from the vicinity of the cloaca. Careful (but necessarily limited) field dissection of one specimen was completed to determine the source of the fluid. Two additional specimens (a male and a female) of the northern form of E. depressa were obtained on 10 June 2006. These were collected along the Great Northern Highway, approximately $180 \mathrm{~km}$ west (by road) of Port Hedland. They were sheltered under a small stone by the roadside, but were $300 \mathrm{~m}$ or more from the nearest significant outcrop of rock. On 13 June 2006 we collected three specimens of the southern form of E. depressa along the North West Coastal Highway, approximately $79 \mathrm{~km}$ by road N-NE of the right angle turn of the highway at Carnarvon.

\section{RESULTS}

Field dissection of the single specimen collected in 2005 revealed the source of the fluids to be a urinary bladder filled with clear liquid. The bladder in E. depressa is a sac positioned posteroventrally 
Table 1 Summary data for specimens of northern (n) and southern (s) forms of Egernia depressa with apparently full urinary bladders. SV = Snout-to-vent length. SV above $100 \mathrm{~mm}$ is considered an adult; other specimens are considered to be juveniles, but not neonates.

\begin{tabular}{|c|c|c|c|c|c|}
\hline WAM-R\# & $\mathrm{n} / \mathrm{s}$ & Sex & Mass (g) & $\mathrm{SV}(\mathrm{mm})$ & Collection Date \\
\hline 167600 & $\mathrm{n}$ & $\mathrm{M}$ & 34.0 & 103 & 4 June 2005 \\
\hline 167606 & $\mathrm{n}$ & $\mathrm{F}$ & 25.0 & 97 & 4 June 2005 \\
\hline 167602 & $\mathrm{n}$ & $\mathrm{F}$ & 34.0 & 103 & 4 June 2005 \\
\hline 167608 & $\mathrm{n}$ & $\mathrm{F}$ & 33.0 & 106 & 4 June 2005 \\
\hline 167609 & $\mathrm{n}$ & $\mathrm{F}$ & 13.0 & 79 & 4 June 2005 \\
\hline 167612 & $\mathrm{n}$ & M & 23.5 & 96 & 4 June 2005 \\
\hline 167613 & $\mathrm{n}$ & $\mathrm{F}$ & 35.5 & 108 & 4 June 2005 \\
\hline 167616 & $\mathrm{n}$ & $\mathrm{M}$ & 37.5 & 106 & 4 June 2005 \\
\hline 167617 & $\mathrm{n}$ & $\mathrm{F}$ & 17.0 & 83 & 4 June 2005 \\
\hline 167618 & $\mathrm{n}$ & $\mathrm{M}$ & 17.0 & 86 & 4 June 2005 \\
\hline 162907 & $\mathrm{n}$ & $\mathrm{M}$ & 18.3 & 83 & 10 June 2006 \\
\hline 162908 & $\mathrm{n}$ & $\mathrm{F}$ & 37.0 & 116 & 10 June 2006 \\
\hline 162909 & $\mathrm{~s}$ & $\mathrm{~F}$ & 42.0 & 112 & 13 June 2006 \\
\hline 162910 & $\mathrm{~s}$ & $\mathrm{~F}$ & 13.5 & 78 & 13 June 2006 \\
\hline 162911 & $\mathrm{~s}$ & M & 35.0 & 94 & 13 June 2006 \\
\hline
\end{tabular}

in the body cavity, with its main portion situated just anterior to the pelvic symphysis and vent. All 10 specimens collected in 2005 had turgid urinary bladders. Body mass, sex, and snout-vent (SV) lengths are provided in Table 1. Extensive rains had passed through the area the week prior to collection (i.e. in late May), and some standing water remained among the rocks. According to Bureau of Meteorology statistics (http://www.bom.gov. au/climate/data/weather-data.shtml), the Wyloo weather station $(8.3 \mathrm{~km}$ from Nanutarra) recorded above-average rainfall of $43.0 \mathrm{~mm}$ in May 2005, making it one of the wettest months of the year.

Both specimens (a male and a female) from the 10 June 2006 collection also had well-distended urinary bladders filled with a clear fluid. In the female (WAM R162908, the bladder measured $2.2 \mathrm{~cm}$ along its anteroposterior axis, and $1.5 \mathrm{~cm}$ along its mediolateral axis. Rainfall data from the Whim Creek Station indicate May and June were dry months in 2006, with recorded rainfall of 0.0 $\mathrm{mm}$ and $1.0 \mathrm{~mm}$, respectively, and a similarly low rainfall was recorded at Roebourne $(0.2 \mathrm{~mm}$ and $0.0 \mathrm{~mm}$, respectively, for May and June). A urinary bladder was also present in all three specimens collected on 13 June 2006, and all appeared full. The Minilya Station recorded rainfall of $9.6 \mathrm{~mm}$ in May 2006 and $4.8 \mathrm{~mm}$ in June 2006.

\section{DISCUSSION}

A urinary bladder was present in both sexes and in the largest and smallest E. depressa specimens we captured (Table 1). The smallest females were $13 \mathrm{~g}$ and $13.5 \mathrm{~g}$ with SV lengths of $79 \mathrm{~mm}$ and 78 $\mathrm{mm}$, respectively. The smallest males were $17 \mathrm{~g}$ (86 $\mathrm{mm} \mathrm{SV})$ and $18.3 \mathrm{~g}$ (83 $\mathrm{mm} \mathrm{SV})$. Neonates born in captivity were previously recorded with SV lengths of $54 \mathrm{~mm}$ to $59 \mathrm{~mm}$ (Day 1980), and a SV length of $100 \mathrm{~mm}$ is considered to be an adult (Cogger 2000; Chapple 2003). None of our specimens are neonates, but our data demonstrate that the urinary bladder is present and functional in both sexes and across a range of body size, including juveniles and adults.

The urinary bladder in these specimens of Egernia was transparent and quite delicate when full (it was easily pierced). These conditions appear to apply to the bladders of at least some other lizards (Beuchat 1986). However, although the urinary bladder of some lizards may be difficult to identify (particularly in preserved specimens), and sometimes is best seen in castings (Beuchat 1986), we were fortunate that in our fresh specimens it was not only a well-developed structure, but was easy to see because it was distended with fluid. Given that all specimens we found had a distended bladder, it seems unlikely that we serendipitously captured in three populations only those members who were in dire need of micturition.

The function of the urinary bladder is not well understood in lizards generally (Minnich 1979; Beuchat et al. 1986). One obvious function of the urinary bladder is as a water storage structure (Bentley 1979; Beuchat et al. 1985, 1986) from which resorption can occur in times of water stress. However, in addition to water balance, the bladder may play a broader role in osmoregulation. The bladder and cloacal membranes of many reptiles also are capable of resorbing sodium from urine, 
and water resorption may be accompanied by ion transport (Bentley 1976, 1979; Shoemaker and Nagy 1977; see also Skadhauge 1977 and Minnich 1979). Surprisingly, the functional significance of urinary bladders in lizards was investigated in detail only three times. In the phrynosomatid Sceloporus jarrovii, the urinary bladder is present in neonates (vestigial in adults) and serves an osmoregulatory function as a fluid reservoir (Beuchat et al. 1986). A water storage function was also suggested for the Namib Desert lizard Aporosaura anchietae by Louw and Holm (1972) and Cooper and Robinson (1990), but in neither case were the authors able conclusively to document such a function. They did suggest that the species retains water in the bladder during periods when water is abundantly available. Long-term osmoregulatory benefit derived from a urinary bladder was recently demonstrated for Heloderma suspectum (Davis and DeNardo 2007); in that species the bladder was shown to hold large quantities of dilute urine for a period of several weeks.

Function of the urinary bladder in E. depressa can only be inferred from circumstantial evidence, and is, therefore, tentative at best (Minnich 1982). However, it seems likely that the urinary bladder plays a role in water storage, and may also serve more complex osmoregulatory functions. Especially in the 2005 collection, abundant water was available on the surface for the week prior to and including the collection date. In all three populations, all specimens we collected had distended bladders. It is interesting that all our specimens were taken in the early winter; although not specifically known for E. depressa, winter hibernation is apparent in most species of the Egernia group (Chapple 2003). Bladder permeability, resorption potential and osmoregulatory functions are unknown in Egernia depressa. Although we do not know the duration over which water can be held in the bladder of that species, the presence of distended bladders following dry months (2006 collection) suggests a potentially significant capacity for long-term water storage.

The presence of a urinary bladder is not documented in other species of Egernia, nor in the newly erected Liopholis, Bellatorias and Lissolepis that now accommodate species previously classified within Egernia (Gardner et al. 2008). A urinary bladder is known to occur in the closely related Tiliqua scincoides and T. rugosa (Goddard 1969; Bentley 1976; Beuchat 1986), which, when combined with the occurrence in E. depressa, provides a phylogenetic bracket that suggests the presence of a bladder in all but the two swamp-dwelling Lissolepis within the Egernia group (based on the strict consensus tree recovered by Gardner et al. 2008).
A distended bladder is apparently common in both northern and southern forms of E. depressa in the late autumn/early winter. It is readily visible, easy to access with dissection, and contains significant fluid at that time of year. These data suggest that E. depressa is an excellent species for field and laboratory investigations of water balance and osmoregulation.

\section{LITERATURE CITED}

Bentley, P.J. (1976). Osmoregulation (pp 365-412). In: Gans, C. and Dawson, W.R. (eds) Biology of the Reptilia. Volume 5. Physiology A. Academic Press: New York, U.S.A.

Bentley, P.J. (1979). The vertebrate urinary bladder: osmoregulatory and other uses. Yale Journal of Biology and Medicine 52: 563-568.

Beuchat, C.A. (1986). Phylogenetic distribution of the urinary bladder in lizards. Copeia 1986: 512-517.

Beuchat, C.A., Braun, E.J. and Vleck, D. (1985). An ephemeral urinary bladder in neonatal lizards. Herpetologica 41: 282-286.

Beuchat, C.A., Vleck, D. and Braun, E.J. (1986). Role of the urinary bladder in osmotic regulation of neonatal lizards. Physiological Zoology 59: 539-551.

Brooks, B. (1906). The anatomy of the internal urogenital organs of certain North American lizards. Transactions of the Texas Academy of Science for 1905 Together with the Proceedings for the Same Year 8: 23-38, Plates 1-4.

Chapple, D.G. (2003). Ecology, life-history, and behavior in the Australian scincid genus Egernia, with comments on the evolution of complex sociality in lizards. Herpetological Monographs 17: 145-180.

Cogger, H.G. (2000). Reptiles and amphibians of Australia (6th edition). Reed New Holland: Sydney, Australia.

Cooper, P.D. and Robinson, M.D. (1990). Water balance and bladder function in the Namib Desert sand dune lizard, Aporosaura anchietae (Lacertidae). Copeia 1990: $34-40$.

Cope, E.D. (1900). The crocodilians, lizards, and snakes of North America. Annual Report of The United States National Museum for 1898, Part II: 153-1294, Plates 1-36.

Davis, J.R. and DeNardo, D.F. (2007). The urinary bladder as a physiological reservoir that moderates dehydration in a large desert lizard, the Gila monster Heloderma suspectum. Journal of Experimental Biology 210: 1472-1480.

Day, K. (1980). Notes on the birth of the pygmy spiny tailed skink, Egernia depressa (Gauthier) in captivity. Herpetofauna 11: 29.

Fox, H. (1977). The urogenital system of reptiles (pp 1-157). In: Gans, C. and Parsons, T.S. (eds), Biology of the Reptilia. Volume 6. Morphology E. Academic Press: New York, U.S.A.

Gabe, M. and Saint Girons, H. (1965). Contribution a la morphologie comparée du cloaque et des glandes épidermoïdes de la région cloacale chez les lépidosauriens. Mémoires du Muséum National d'Histoire Naturelle, n.s., Série A, Zoologie 33: 149-292, Plates 1-15. 
Gardner, M.G., Hugall, A.F., Donnellan, S.C., Hutchinson, M.N. and Foster, R. (2008). Molecular systematics of social skinks: phylogeny and taxonomy of the Egernia group (Reptilia: Scincidae). Zoological Journal of the Linnean Society 154: 781-794.

Goddard, C.K. (1969). Mechanics of the urinary bladder of the lizard Tiliqua scincoides scincoides (Shaw). Australian Journal of Experimental Biology and Medical Science 47: 701-711.

Louw, G.N. and Holm, E. (1972). Physiological, morphological and behavioural adaptations of the ultrapsammophilous, Namib Desert lizard Aporosaura anchietae (Bocage). Madoqua, Series II 1: 67-85.

Minnich, J.E. (1979). Reptiles (pp. 391-641). In: Maloiy, G.M.O. (ed.), Comparative physiology of osmoregulation in animals. volume 1. Academic Press: New York, U.S.A.

Minnich, J.E. (1982). The use of water (pp 325-395). In: Gans, C. and Pough, F.H. (eds), Biology of the Reptilia.
Volume 12. Physiology C. Academic Press: New York, U.S.A.

Mulaik, D. de M. (1946). A comparative study of the urinogential systems of an oviparous and two ovoviviparous species of the lizard genus Sceloporus. Bulletin of the University of Utah 37: 1-24.

Reynolds, A.E. (1939). Some gross anatomical relations of the male urogenital system and other internal organs in Eumeces fasciatus. Proceedings of the Indiana Academy of Science 49: 233-242.

Shoemaker, V.H. and Nagy, K.A. (1977). Osmoregulation in amphibians and reptiles. Annual Review of Physiology 39: 449-471.

Skadhauge, E. (1977). Excretion in lower vertebrates: function of gut, cloaca, and bladder in modifying the composition of urine. Federation Proceedings 36: 2487-2492.

Manuscript received 3 July 2009; accepted 10 February 2010. 